\title{
Iron absorption stimulation by administration of soy protein hydrolysates containing bioactive peptides in rats
}

\author{
Ida Susanti*, Noer Laily, Galih Kusuma Aji, Muhamaludin, Haris Muhamad Ikhsan \\ Center for Technology of Agroindustry - Gd. LAPTIAB (610) BPPT, PUSPIPTEK Serpong, Tangerang Selatan, Banten, Indonesia, 15314
}

\begin{abstract}
The prevalence of iron deficiency anemia in Indonesia is high. Most of the anemia is caused by iron deficiency syndrome due to inadequate iron intake and low bioavailability of iron sources. Some studies indicated that bioactive peptides from certain protein hydrolysates could support iron absorption. Our previous study showed that soy protein hydrolysates containing bioactive peptides indicated an iron-binding activity and could increase its solubility in water. Aim of this study was to investigate the effect of soy protein hydrolysates administration on iron serum levels in anemic Sprague Dawley rats. Anemia induction was performed by applying $\mathrm{NaNO}_{2}(0.5 \mathrm{mg} / \mathrm{ml}$ per $200 \mathrm{~g}$ body weight (BW) of rats per day for 14 days) orally. The experiment was carried out in a completely randomized design, consisting of six groups. The first group was the control normal group $(\mathrm{N})$, without induction and the others were treatment groups that were induced with $\mathrm{NaNO}_{2}$ and supplemented with iron $(0.3 \mathrm{mg} / 200 \mathrm{~g} \mathrm{BW})$, consisted of control group (CMC), control iron (Fe) group, iron and soy protein hydrolysate-1 (270 mg/200 g BW) (FeSH-1) group, iron and soy protein hydrolysate-2 $(270 \mathrm{mg} / 200 \mathrm{~g} \mathrm{BW}$ ) (Fe-SH2) group and positive control iron vitamin C $(0.24 \mathrm{mg} / 200 \mathrm{~g} \mathrm{BW})$ (Fe Vit. C) group. The result showed that Fe-SH2 treatment group had a better iron-binding capacity rather than other groups. This result suggests that soy protein hydrolysates could enhance iron absorption, which might be applied in human as a functional food to reduce anemia prevalence.
\end{abstract}

Article history:

Received 18 Feb 2020

Revised 21 Feb 2020

Accepted 26 Feb 2020

Available online 29 Feb 2020

Keywords:

Anemia

iron

soy protein hydrolysate in vivo

*Corresponding author: bessa27@yahoo.com
DOI: $10.5614 / \mathrm{crbb} .2019 .1 .2 / \mathrm{DKPB} 8204$

\section{Introduction}

Iron is one of the micro minerals that are very crucial for the body because it is a significant component in haemoglobin $(\mathrm{Hb})$ (Abbaspour et al., 2014; López and Martos, 2004). The main function of iron is to transport oxygen from the lungs to the tissues and deliver electrons in the energy forming process in cells. Iron also helps in various activities such as cellular transport of oxygen in hemoglobin and myoglobin, transporting electrons in various cytochrome and ferredoxin in the respiratory system (Gupta, 2004; Li et al., 2017; Umbreit, 2005). Iron deficiency can lead to anemia by causing the body to become fatigued and lethargic, more susceptible to disease, as well as decreased physical activity and performance (Camaschella, 2015). In children and adolescents, it also affects the concentration and learning ability (cognitive) (Camaschella, 2015; Ferrara et al., 2006; López and Martos, 2004). While for pregnant women, anemia due to iron deficiency could increase the risk of maternal and child mortality, miscarriage, stillbirth, premature or low birth weight (Allen, 2000; Scholl and Reily, 2000).

Anemia prevalence in 2013 due to iron deficiency in Indonesia was high, which were about $37.1 \%$ in pregnant women, while in adolescent girls ( $\geq 15$ years) were approximately $22.7 \%$ (BALITBANGKES, 2013). Recently, anemia prevalence in pregnant women increased to $48.9 \%$ (BALITBANGKES, 2018). Thus, anemia prevention becomes Indonesian government attention. Iron deficiency anemia mostly is caused by inadequate of iron from food intake (Camaschella, 2015), and lower bioavailability of iron
e-ISSN 2686-1623/C 2020 Institut Teknologi Bandung. All rights reserved

sources (Collings et al., 2013; Hurrell and Egli, 2010; Prihatini et al., 2009; Tatala et al., 1998). To fight the iron-deficiency anemia, a multifactor approach is required, including iron fortification in food and addition of active substances that can support iron absorption. Iron fortification in food has been applied as a solution to meet iron needs, such as in milk (Hertrampf et al., 2001) wheat flour (Hertrampf, 2002), fish sauce (Garby et al., 1974; Thuy et al., 2003) and soy sauce (Huo et al., 2002). Iron fortification in milk contributed to reducing the incidence of anemia from $27.3 \%$ to $8.8 \%$ (refs). In addition to food products, iron was also fortified in salt $(1 \mathrm{mg} \mathrm{Fe} / \mathrm{g}$ ) with a success rate for decreasing anemia incidence by $27 \%$ (Zimmermann et al., 2003).

Another approach to increase iron absorption is by adding bioactive compounds that can bind iron, such as protein hydrolysates. The positive effects of protein hydrolysates on the absorption of minerals such as iron and other minerals had also been reported both in vitro and in vivo studies (Kibangou et al., 2005; Li et al., 2017). In vitro studies on Caco-2 cell lines showed an increase of four-fold higher absorption of iron when was given in the form of $\mathrm{Fe}^{2+}$-SVNPLY peptide bond complex than in the form of iron sulfate salts (Eckert et al., 2016). Other bioactive peptides, calcium-binding phosphopeptides (CPP) which are derived from milk, showed activity to bind iron (Ait-Oukhatar et al., 1997; AniKibangou et al., 2005; Bouhallab et al., 1999). Study in irondeficient mice, supplementation of a diet of iron chelate with multiple amino acids (Iron multi-amino acid chelate/IMAAC) could significantly increase Haemoglobin $(\mathrm{Hb})$ concentration (Kajarabille et al., 2017). Therefore, it can be implied that protein hydrolysates 
for chelating iron are a good promoter to increase iron bioavailability to be absorbed in the lumen. In our previous study, soy protein hydrolysate that successfully developed can act to support the absorption of iron by chelating iron in vitro studies (unpublished data). To date, not yet confirmed how the effect of administration of soy protein hydrolysates containing bioactive peptides on iron absorption in vivo. Thus, the purpose of this study was to observe the effect of administration of soy protein hydrolysate containing bioactive peptides on serum iron levels and Haemoglobin $(\mathrm{Hb})$ in experimental rats.

\section{Materials and methods}

\subsection{Chemicals and reagents}

The chemicals used for serum iron analysis were ammonium iron (II) sulphate (Merck), potassium permanganate (Merck), potassium thiocyanate (Merck), potassium sulfate (Merck), sodium tungstate (Merck). Ferrous sulphate (Merck) were used for iron supplementation in treatment groups, and ascorbic acid (Merck) was used for vitamin $\mathrm{C}$ supplementation in the positive control group. Also, sodium nitrite (Merck) was used for $\mathrm{Hb}$ depletion. A standard diet of the American Institute of Nutrition (AIN-76A) was provided as feed.

\subsection{Soy protein hydrolysates}

Both of soy protein hydrolysates containing bioactive peptides were prepared and supplied by the Functional Food Laboratory, Center for Technology of Agroindustry, BPPT. Soy protein hydrolysate was made from the local variety and non-genetically modified organism (GMO) soybean, Anjasmoro, by applying a thermal process under high pressure which was continued with hydrolysis using bromelain enzyme. Soy protein hydrolysate- 1 was made by applying spray-drying to the supernatant from enzymatic hydrolysis of soybeans, whereas soy protein hydrolysate- 2 was a whole soy enzymatic hydrolysis product without supernatant separation. The nutrition information of soy protein hydrolysates can be seen in Table 1 .

Table 1. Nutrition content of soy hydrolysate (in $100 \mathrm{~g}$ )

\begin{tabular}{llll}
\hline Item & Unit & SH-1 & SH-2 \\
\hline Water content & $\%$ & 2.68 & 85.88 \\
Ash & $\%$ & 2.32 & 0.67 \\
Protein & $\%$ & 18.27 & 6.60 \\
Fat & $\%$ & 1.06 & 3.12 \\
Carbohydrate & $\%$ & 75.67 & 3.73 \\
Dietary fiber & $\%$ & 15.20 & not provided \\
Iron & ppm & 27.7 & 9.09 \\
*SH: soy protein hydrolysate &
\end{tabular}

\subsection{Animal studies}

In this study, the experimental protocol had been approved by the ethics committee, faculty of medicine, University of Indonesia. Five-weeks-old male rats (Rattus novergicus) strain Sprague Dawley were purchased from Badan Pengawas Obat dan Makanan (BPOM) Jakarta. All rats were housed in a light-dark cycle and a temperature-controlled room with ad libitum access to diet and water.

After a week of acclimation, the treated rats were induced for anemia, while the other rats were not induced as a normal control group (N). Ambarwati's method to induce anemia condition in rats was applied with some modifications, giving sodium nitrite solution (1.5 $\mathrm{mg}$ in $3 \mathrm{ml}$ of aquades/200 $\mathrm{g}$ Body Weight (BW) of rat/day) for two weeks (Ambarwati, 2012).

The anemia-induced groups were, then, randomly divided into five groups (6 rats each) and supplemented with iron $(0.3 \mathrm{mg} / 200$ $\mathrm{g}$ BW which equal to $10 \mathrm{mg} / \mathrm{kg}$ BW in humans, except for CMC group that functioned as control treated group (CMC 0.5\%). The treatment groups were as followed, group $\mathrm{Fe}$ acted as a negative control (iron only), FeSH-1 (iron and $270 \mathrm{mg} / 200 \mathrm{~g}$ BW soy protein hydrolysate-1), FeSH-2 (iron and $270 \mathrm{mg} / 200 \mathrm{~g}$ BW soy protein hydrolysate-2) and FeVit.C (iron and vitamin C $0.24 \mathrm{mg} / 200 \mathrm{~g} \mathrm{BW}$ ) which functioned as positive control. Vitamin $\mathrm{C}$ used is equivalent to $70 \mathrm{mg}$ in human as daily nutritional adequacy. All samples were dissolved in $0.5 \%$ CMC. Samples were given orally every day for four weeks.

Body weight was measured every week using an analytical balance. Blood was collected every week for serum iron analysis. In the first and last week, an additional analysis was performed to measure $\mathrm{Hb}$ using the Haematoanalyzer at Laboratorium Kesehatan Daerah (Labkesda), Tangerang Selatan.

\subsection{Analysis of serum iron}

Analysis of serum iron was carried out by using spectrophotometer according to a previous publication (Rini, 2003). Serum iron measurement was carried out in triplicate.

Iron stock-standard solution: in a 500-ml volumetric flask, $0.3512 \mathrm{~g}$ iron ammonium sulfate were dissolved in $50 \mathrm{ml}$ of distilled water then added with $2.5 \mathrm{ml}$ of concentrated sulfuric acid solution. Into the solution, potassium permanganate was added slowly until the color stabilized. The mixture was then diluted to a volume of $500 \mathrm{ml}$ with distilled water.

Sample preparation: in a $50-\mathrm{ml}$ volumetric flask, $0.5 \mathrm{ml}$ of blood, two $\mathrm{ml}$ of concentrated sulphuric acid, and $2 \mathrm{ml}$ of potassium persulphate were diluted with $25 \mathrm{ml}$ of distilled water. Two $\mathrm{ml}$ of $10 \%$ sodium tungstate was added into the solution, mixed well, and let cold at room temperature. The mixture was then diluted to a volume of $50 \mathrm{ml}$ with distilled water. The solution was filtered and collected in a dry tube.

Serum iron determination: into $10 \mathrm{ml}$ of blood filtrate/standard/blank, amount of $0.5 \mathrm{ml}$ concentrated potassium persulphate and $2 \mathrm{ml}$ of $3 \mathrm{~N}$ potassium thiocyanate were added, mixed well and read at $470 \mathrm{~nm}$ with a spectrophotometer. Measurement was analyzed by comparing with the equation from the standard calibration curve.

\subsection{Data analysis}

Obtained data, serum iron and Hb were subjected to statistical analysis using ANOVA using SPSS 13. Least Significant Difference (LSD) test was performed to investigate in which group the result differs. P-values of $<0.05$ were considered significant. All results are presented as mean \pm standard deviation (SD).

\section{Results and discussion}

\subsection{Effect of soy protein hydrolysate on rat body weight}

The body weight of all experimental rats increased throughout the study, even in the treatment group of FeSH-1 and FeSH-2 as indicated in Fig. 1. This result suggests that administration of soy hydrolysate did not have any adverse effect for rats specifically in feed consumption and body weight gain.

\subsection{Effect of soy protein hydrolysate administration on serum ion}

The impact of administration soy protein hydrolysate was monitored by observing the weekly delta changes in serum iron levels. Based on the obtained result in Fig. 2, it appears that administration of soy protein hydrolysate in the FeSH-1and FeSH-2 groups significantly increased the mean serum iron level $(\mathrm{p}<0.05)$ when compared to the control group N, CMC and Fe from the first week (W1) to the third week (W3).

Serum iron is depicted the iron concentration in the blood due to iron metabolisms such as iron absorption from the foods, iron transportation into the cell, and other excretion from the blood vessel (Camaschella, 2015). In this study, there was an increase of serum iron levels, after administration of soy protein hydrolysate 
for four weeks. FeSH-2 group showed a significant difference in week 1 with $\mathrm{N}$. In week 2 and 3 after the treatment, delta iron of FeSH-1, FeSH-2 and Fe Vit. C was always significantly higher compared to N, CMC and Fe. However, in week four, we could not find any difference between all of the treatments.

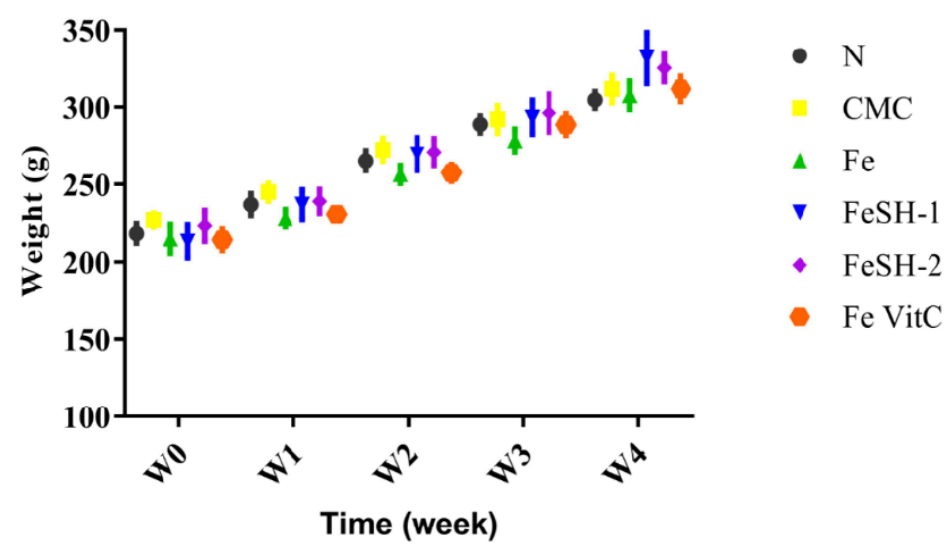

Fig. 1. Effect of soy hydrolysate on experimental rat body weight

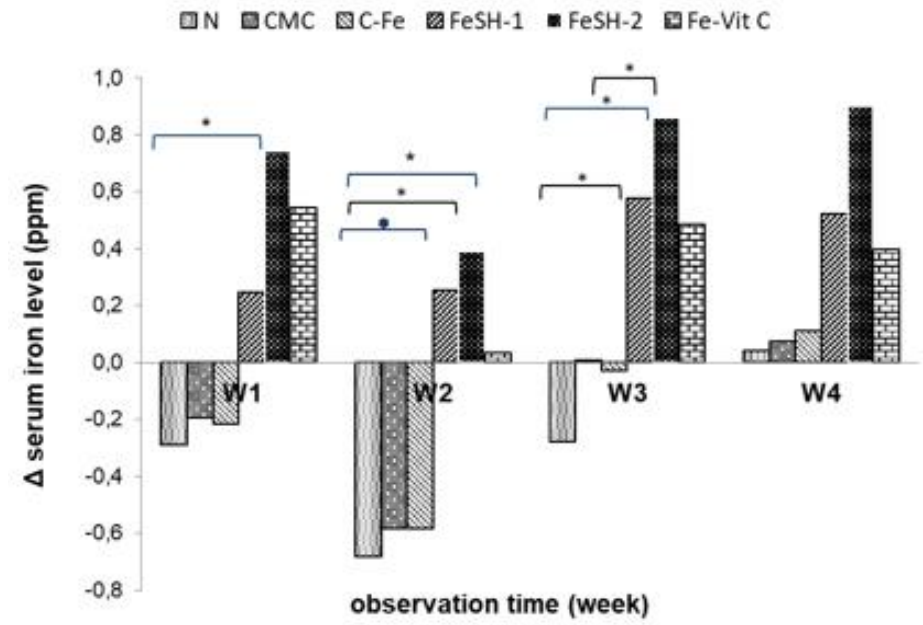

Fig. 2. Effect of administration of soy hydrolysate on serum iron level

In this study, soy protein was hydrolysed by bromelain enzyme to produce peptides that are responsible for iron chelation process. The result indicates that soy protein hydrolysate can increase iron absorption. Li et al. (2017) stated that chelation ability of protein hydrolysates is a critical factor in the promotion of iron absorption. Through metal chelation, peptides or amino acids increase the solubility and bioavailability of metals. Therefore, iron-chelatable protein hydrolysates are potential promoters of iron absorption. The iron-chelating activity of soy hydrolysate was also reported by other studies (Lv et al., 2013; Zhang et al., 2014). Zhang et al. (2014), reported that the iron-binding capacity of dephytinized soy isolate was influenced by the degree of hydrolysis $(\mathrm{DH})$ and enzyme type. The hydrolysate with moderate DH (6.69\%) achieved $3.87 \pm 0.14 \mathrm{mg}$ EDTA/g-protein of iron-binding capacity, which was higher than the hydrolysate with high $(9.89,10.87$ and $11.17 \%)$ or low $(0$ and 4.99\%) DH. Another bioactive peptide from milk-casein that can help bind iron and enhance iron absorption is Calcium-binding phosphopeptides (CPP). In vivo studies revealed and confirmed its iron-binding activity (Ait-Oukhatar et al., 1997; Ani-Kibangou et al., 2005; Bouhallab et al., 1999). One study in human also found the same function as iron absorption enhancer (Ait-Oukhatar et al., 2002). The mechanism of iron-binding process can involve various levels of protein hydrolysis product, namely amino acids (glycine, methionine, glutamine, and aspartate), di-, tri-, and tetra-peptide which contain oxygen groups in phosphate (serine), and carboxyl (glutamine and aspartate), as well as oligopeptide and protein (Li et al., 2017). Review paper explained that there might be three mechanisms on how protein hydrolysates can increase iron absorption, 1) through increased mineral solubilization, 2) reduction of ferric iron to Ferro, and 3) the binding between iron and amino acids or peptides to enhance absorption through the absorption pathway of peptides (Li et al., 2017).

Also, in this study, vitamin C was used as a positive control because of its nature as an activator for iron absorption. Vitamin C is an activator that can increase iron absorption by reducing ferric ion to ferro and prevents the formation of ferrous hydroxide complex, which is insoluble (Benito and Miller, 1998).

\subsection{Effect of soy protein hydrolysate on haemoglobin}

Delta $\mathrm{Hb}$ after four weeks of treatment of soy hydrolysate or other treatments for each group was depicted in Fig. 3. The result indicated that $\mathrm{Hb}$ level was increased significantly higher than untreated control iron (N) after administration of iron ( $\mathrm{Fe}$ ), iron and soy protein hydrolysate-1 (FeSH-1) as well as iron and soy protein hydrolysate-2 (FeSH-2). FeSH-2 had the highest rise of $\mathrm{Hb}$ concentration compared to other treatment groups $(1,533 \mathrm{mg} / \mathrm{dl})$. This finding was in line with the serum iron level at FeSH-2 group which also had the highest increase of serum iron concentration. Iron has an important role in the synthesis of haemoglobin due to the major component of $\mathrm{Hb}$ (Abbaspour et al., 2014; López and Martos, 2004). Haemoglobin is the oxygen transport protein which consists of 4 polypeptide chain, each of which contains one iron ion which has a role as oxygen binding site (Gupta, 2014).

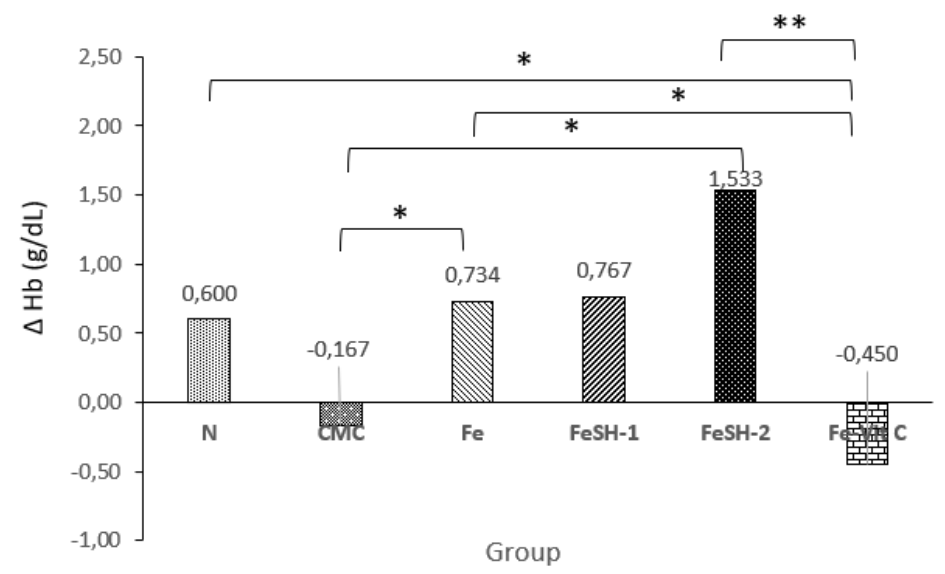

Fig. 3. Effect of administration of soy hydrolysate on $\mathrm{Hb}$ level

On the other hand, the $\mathrm{Hb}$ level in group $\mathrm{FeSH}-2$ was significantly higher than the group of positive control Fe Vit. C $(\mathrm{p}<0.01)$, this result could be understood since the serum iron level was lower than group FeSH-2. Vitamin $\mathrm{C}$ is one of the best iron absorption enhancers. However, it is unstable during storage or another process. Thus, why soy protein hydrolysate containing bioactive peptide resulted in a better enhancement of iron absorption rather than vitamin $C$ could be explained in accordance to Eckert study (Eckert et al, 2016), showing peptide chelators derived from barley proteins may provide an alternative option to enhance $\mathrm{Fe}^{2+}$ absorption since they were more stable during storage rather than vitamin $\mathrm{C}$.

\section{Conclusion}

In this study, soy protein hydrolysate containing bioactive peptides was examined for its activity on the absorption of iron in vivo. The result showed that soy protein hydrolysate could stimulate iron absorption, as shown by the increase in serum ironBesides, this study also found that group that receiving soy protein hydrolysate-2 (FeSH-2) resulted in a higher increase of $\mathrm{Hb}$ level. Soy protein hydrolysate-2, thus, can act as an iron chelator which can further be applied as functional foods for preventing iron deficiency anemia. 


\section{Acknowledgement}

Authors thank Center for Technology of Agroindustry - BPPT for providing fund and facilities for the research.

\section{Conflict of Interest}

The authors declare there is no conflict of interest in this study.

\section{References}

Abbaspour N, Hurrell R, Kelishadi R. 2014. Review on iron and its importance for human health. J Res Med Sci: The official journal of Isfahan University of Medical Sciences 19(2): 164.

Ait-Oukhatar N, Bouhallab S, Bureau F, Arhan P, Maubois J-L, Drosdowsky MA, Bouglé DL. 1997. Bioavailability of casein phosphopeptide bound iron in the young rat. $J$ Nutr Biochem 8(4): 190-4. doi: $10.1067 / \mathrm{mlc} .2002 .128146$

Ait-Oukhatar N, Peres JM, Bouhallab S, Neuville D, Bureau F, Bouvard G, Arhan P, Bougle D. 2002. Bioavailability of caseinophosphopeptidebound iron. $J$ Lab Clin Med 140(4): 290-4. doi: $10.1067 / \mathrm{mlc} .2002 .128146$

Allen LH. 2000. Anemia and iron deficiency: effects on pregnancy outcome. Am J Clin Nutr 71(5): 1280S-4S. doi: 10.1093/ajcn/71.5.1280s

Ambarwati R. 2012. Effect of sodium nitrite (NaNO2) to erithrocyte and hemoglobin profile in white rat (Rattus norvegicus). Folia Medica Indonesiana 48(1): 1-5.

Ani-Kibangou B, Bouhallab S, Mollé D, Henry G, Bureau F, Neuville D, Arhan P, Bouglé D. 2005. Improved absorption of casein phosphopeptidebound iron: role of alkaline phosphatase. J Nutr Biochem 16(7): 398 401. doi: 10.1016/j.jnutbio.2005.02.008

BALITBANG Kemenkes RI. 2013. Research on elementary health (RISKESDAS) 2013 (in Indonesia). Balitbang Kemenkes RI, Jakarta.

BALITBANG Kemenkes RI. 2018. Research on elementary health (RISKESDAS) 2013 (in Indonesia). Balitbang Kemenkes RI, Jakarta.

Benito P, Miller D. 1998. Iron absorption and bioavailability: an updated review. Nutr Res 18(3): 581-603. doi: 10.1016/S0271-5317(98)00044 $\mathrm{X}$

Bouhallab S, Oukhatar NA, Mollé D, Henry G, Maubois JL, Arhan P, Bouglé DL. 1999. The sensitivity of $\beta$-casein phosphopeptide-iron complex to digestive enzymes in ligated segment of rat duodenum. $J$ Nutr Biochem 10(12): 723-7. doi: 10.1016/S0955-2863(99)00062-5

Camaschella C. 2015. Iron-deficiency anemia. New Engl J Med 372(19): 1832-43. doi: 10.1056/NEJMra1401038

Collings R, Harvey LJ, Hooper L, Hurst R, Brown TJ, Ansett J, King M, Fairweather-Tait SJ. 2013. The absorption of iron from whole diets: a systematic review. Am $J$ Clin Nutr 98: 65-81. doi: 10.3945/ajen.112.050609

Eckert E, Lu L, Unsworth LD, Chen L, Xie J, Xu R.2016. Biophysical and in vitro absorption studies of iron-chelating peptide from barley proteins. J Funct Foods 25: 291-301. doi: 10.1016/j.jff.2016.06.011

Ferrara M, Coppola L, Coppola A, Capozzi L. 2006. Iron deficiency in childhood and adolescence: a retrospective review. Hematology 11(3): 183-6. doi: 10.1080/10245330600775105

Garby L, Areekul S, Chantachum Y, Deesin T, Garby J, Kongrod S, Matrakul D, Punnavutti V, Surathint K, Thirachantra S. 1974. Iron supplementation in Thai fish sauce. Annals Tropic Med Parasitol 68(4): 467-76. doi: 10.1080/00034983.1974.11686972.
Gupta CP. 2014. Role of iron (Fe) in body. IOSR J Appl Chem (IOSR-JAC) 7(11): 38-46. doi: 10.9790/5736-071123846

Hertrampf E. 2002. Iron fortification in the Americas. Nutr Rev: 60(suppl_7): S22-5. doi: 10.1301/002966402320285056

Hertrampf E, Olivares M, Pizarro F, Walter T. 2001. Impact of iron-fortified milk in infants: evaluation of effectiveness. Ann Nutr Metab 45(suppl 1): 117 .

Huo J, Sun J, Miao H, Yu B, Yang T, Liu Z, Lu C, Chen J, Zhang D, Ma Y, Wang A, Li Y. 2002. Therapeutic effects of NaFeEDTA-fortified soy sauce in anaemic children in China. Asia Pac J Clin Nutr 11(2): 123-7. doi: 10.1046/j.1440-6047.2002.00277.x

Hurrell R, Egli I. 2010. Iron bioavailability and dietary reference values. $A m$ J Clin Nutr 91(5): 1461S-7S. doi: 10.3945/ajen.2010.28674F

Kajarabille N, Brown C, Cucliciu A, Thapaliya G, Latunde-Dada GO 2017. Bioavailability of iron multi-amino acid chelate preparation in mice and human duodenal HuTu 80 cells. Brit J Nutr 117(6): 767-74. doi: $10.1017 /$ S0007114517000186

Kibangou IB, Bouhallab S, Henry G, Bureau F, Allouche S, Blais A, Guérin P, Arhan P, Bouglé DL. 2005. Milk proteins and iron absorption: contrasting effects of different casein phosphopeptides. Pediatr Res 58(4): 731-4. doi: 10.1203/01.PDR.0000180555.27710.46

Li Y, Jiang H, Huang G. 2017. Protein hydrolysates as promoters of nonhaem iron absorption. Nutrients 9(6): 609. doi: 10.3390/nu9060609

López MA, Martos FC. 2004. Iron availability: an updated review. Int J Food Sci Nutr 55(8): 597-606. doi: 10.1080/09637480500085820

Lv Y, Bao X, Liu H, Ren J, Guo S. 2013. Purification and characterization of calcium-binding soybean protein hydrolysates by $\mathrm{Ca} 2+/ \mathrm{Fe} 3+$ immobilized metal affinity chromatography (IMAC). Food Chem 141(3): 1645-50. doi: 10.1016/j.foodchem.2013.04.113

Prihatini S, Kartika V, Sari YD. 2009. Meat consumption as anemia indicators in productive women (in Indonesia). Penelitian Gizi dan Makanan 32(2): 112-21.

Rini DM. 2003. Iron efectivity from cow's bone marrow as supplements in prevention of anemia (in Indonesia). Bogor: IPB (Bogor Agricultural University).

Scholl TO, Reilly T. 2000. Anemia, iron and pregnancy outcome. J Nutr 130(2): 443S-7S. doi: 10.1093/jn/130.2.443S

Tatala S, Svanberg U, Mduma B. 1998. Low dietary iron availability is a major cause of anemia: a nutrition survey in the Lindi District of Tanzania. Am J Clin Nutr 68(1): 171-8. doi: 10.1093/ajcn/68.1.171

Thuy VP, Berger J, Davidsson L, Khan NC, Lam NT, Cook JD, Hurrell RF, Khoi HH. 2003. Regular consumption of NaFeEDTA-fortified fish sauce improves iron status and reduces the prevalence of anemia in anemic Vietnamese women. Am $J$ Clin Nutr 78(2): 284-90. doi: 10.1093/ajcn/78.2.284

Umbreit J. 2005. Iron deficiency: a concise review. Am J Hematol 78(3): 225. doi: $10.1002 /$ ajh.20249

Zhang M-N, Huang G-R, Jiang J-X. 2014. The iron-binding capacity of dephytinised soy protein isolates hydrolysate as influenced by the degree of hydrolysis and enzyme type. J Food Sci Technol 51(5): 994-9. doi: 10.1007/s13197-011-0586-7

Zimmermann MB, Zeder C, Chaouki N, Saad A, Torresani T, Hurrell RF. 2003. Dual fortification of salt with iodine and microencapsulated iron: a randomized, double-blind, controlled trial in Moroccan schoolchildren. Am J Clin Nutr 77(2): 425-32. doi: 10.1093/ajen/77.2.425 